\title{
Co-invention Project in the Physics Curriculum on the Lower Secondary School
}

\section{Milan Kováč}

Comenius University in Bratislava, Slovakia, vac.milanko@gmail.com

\begin{abstract}
As an integral part of the innovation of Physics Curriculum, we consider involvement of a co-invention project - a small teamwork of the pupils on the tasks developed by themselves - project, lasting 10-15 teaching hours, with focused goal oriented on innovation of a product. Pupils are scaffolded in well-designed learning environment, by well-designed printed material and specially trained physics teacher in an equipped physics laboratory. As our endeavour to meet such a goal, we have started by initial pilot projects, in which 13-years old pupils constructed products from a very limited material, using a limited equipment. The project itself is directed to take into consideration each of the sights - scientific (physics as a school subject, part of the sciences, how does the nature work); engineering (physics as a school subject, part of the technology education); collaborative design (work of small teams, which consider also whole school community and experts from out of schools environment) and discussing entrepreneurial practices (considering usable products, create marketing plan). The pupils are systematically lead to develop each of these four sights via six stages - idea generation, activity (planning, designing), knowledge seeking, evaluation of invention, justifying solution, knowledge building. Such a complex activity performed by 13 years old pupils can be considered as too ambitious. Of course, we are modifying whole physics education and we are preparing pupils to be able to work in teams, discuss, measure physical quantities, articulate their ideas and work with various sources of information. In the article, we proudly inform about happy pupils, which like physics (and also school subject - physics) and prove their knowledge on a higher level than their peers, after one year of testing our new methodologies. Moreover, we start to measure the level of their engineering competences and hypothesize, that it should be developed better, than of their peers educated by traditional means.
\end{abstract}

Keywords: innovation, invention, project, product. 


\section{Introduction}

Let us start with goals of physics education. 5 years ago we proclaimed, that we fulfill three main domains of goals: A. goals (and content) related to attitudes of society towards science; B. goals (and content) related to methods of science; C. goals (and content) related to pieces of knowledge. Last part we divided to $\mathrm{C} 1$.pieces of knowledge for development of scientific methods and attitudes towards science; C2.pieces of knowledge related to the quality of living and general scientific culture. (Demkanin, P. 2013). Even if we try to fulfill such goals, students in many educational systems often doubt relevance of what they have been taught on physics lessons. They do not see any meaning of what they learn, it does not make any sense for them. Science is often unappealing and unattractive for them because they have wrong impression that science is a bunch of boring facts, definitions and laws. This may be caused by teaching focused on contents of science only (National Research Council. 2012).

Science education from the perspective of majority of science teachers (in many countries) is quite stable. But changes in society are relatively fast, and this is true also in the aspects closely related to the science education. Information is easily accessible (generally, not from the perspective of pupils), the speed of communication has risen significantly; our pupils use the equipment, which was available only in some top laboratories some decades ago. Science education should also reflect great changes of society, like globalisation, climatic changes, terrorism, boom of automotive and building industry; and, in many countries, also radical political changes and economic crisis. On the other hand, the processes of the mind of our children are still the same.(Demkanin, P. 2013).

Modern, innovative education of science proclaims idea that students should not be taught bare facts and information only, but also science and engineering practices. Acquiring skills in these practices allows better understanding of how science knowledge is formed and how engineering solutions are developed. This helps students to develop more critical opinion on scientific information, but also to form profound knowledge and deep understanding of phenomena The actual doing of science or engineering can also challenge students and stimulate their curiosity and interest. (National Research Council. 2012)

In this article we present a school project. Our goal is to facilitate students to develop a product, having in mind four aspects: science, engineering, design and entrepreneurship (Table 1). Via the processes involved, we would like to link many aspects of science education. 
Table 1. Four aspects of co-invention practices

\begin{tabular}{|c|c|c|c|c|}
\hline & Science & Engineeging & Design & Enterpreneurship \\
\hline $\begin{array}{l}\text { Epistemic } \\
\text { focus }\end{array}$ & Posing questions & $\begin{array}{l}\text { Defining and } \\
\text { solving problems }\end{array}$ & $\begin{array}{l}\text { Analyzing design } \\
\text { challenges }\end{array}$ & $\begin{array}{l}\text { Finding entrepreneurial } \\
\text { challenges \& } \\
\text { possibilities }\end{array}$ \\
\hline $\begin{array}{l}\text { Idea } \\
\text { generation }\end{array}$ & $\begin{array}{l}\text { Generating } \\
\text { working theories } \\
\text { and models }\end{array}$ & $\begin{array}{l}\text { Envisioning } \\
\text { potential } \\
\text { solutions/models }\end{array}$ & $\begin{array}{l}\text { Coming up with } \\
\text { design ideas } \\
\text { (ideation) }\end{array}$ & $\begin{array}{l}\text { Making entrepreneurial } \\
\text { initiatives }\end{array}$ \\
\hline $\begin{array}{l}\text { Typical } \\
\text { activity }\end{array}$ & $\begin{array}{l}\text { Planning and } \\
\text { carrying out } \\
\text { investigations } \\
\text { regarding models } \\
\text { constructed }\end{array}$ & $\begin{array}{l}\text { Constructing and } \\
\text { exploring } \\
\text { artefacts } \\
\text { embodying } \\
\text { solutions }\end{array}$ & $\begin{array}{l}\text { Explicating } \\
\text { design ideas } \\
\text { conceptually, } \\
\text { visually and/or } \\
\text { materially } \\
\end{array}$ & $\begin{array}{l}\text { Working out } \\
\text { entrepreneurial } \\
\text { alternatives to be } \\
\text { reflected and tested }\end{array}$ \\
\hline $\begin{array}{l}\text { Knowledge } \\
\text { seeking }\end{array}$ & $\begin{array}{l}\text { Analyzing and } \\
\text { interpreting data; } \\
\text { seeking new } \\
\text { knowledge for } \\
\text { making sense }\end{array}$ & $\begin{array}{l}\text { Determining } \\
\text { criteria and } \\
\text { analyzing how } \\
\text { different } \\
\text { solutions satisfy } \\
\text { requirements }\end{array}$ & $\begin{array}{l}\text { Analyzing } \\
\text { internal } \\
\text { (determined by } \\
\text { design team) and } \\
\text { external } \\
\text { (collected from } \\
\text { users) constraints }\end{array}$ & $\begin{array}{l}\text { Analyzing already } \\
\text { existing enterprises for } \\
\text { finding new } \\
\text { possibilities; examining } \\
\text { social or customer } \\
\text { needs across segments }\end{array}$ \\
\hline $\begin{array}{l}\text { Evaluation } \\
\text { of } \\
\text { inventions }\end{array}$ & $\begin{array}{l}\text { Visualizing and } \\
\text { modelling } \\
\text { results, using } \\
\text { computational } \\
\text { means when } \\
\text { appropriate }\end{array}$ & $\begin{array}{l}\text { Constructing and } \\
\text { testing prototypes } \\
\text { (making models } \\
\text { and simulations) }\end{array}$ & $\begin{array}{l}\text { Constructing } \\
\text { mock ups or } \\
\text { prototypes and } \\
\text { exploring and } \\
\text { testing their } \\
\text { features }\end{array}$ & $\begin{array}{l}\text { Generating alternative } \\
\text { entrepreneurial ideas, } \\
\text { using initial impact or } \\
\text { market studies for } \\
\text { assessing promise (e.g., } \\
\text { meeting needs, solving } \\
\text { societal problems) }\end{array}$ \\
\hline $\begin{array}{l}\text { Justifying } \\
\text { solutions }\end{array}$ & $\begin{array}{l}\text { Using evidence } \\
\text { to justify } \\
\text { arguments (or } \\
\text { starting new } \\
\text { investigative } \\
\text { cycle) }\end{array}$ & $\begin{array}{l}\text { Determining } \\
\text { optimal solution } \\
\text { through } \\
\text { systematic } \\
\text { comparison of } \\
\text { alternatives (or } \\
\text { going back to } \\
\text { seeking new } \\
\text { solutions) }\end{array}$ & $\begin{array}{l}\text { Finding adequate } \\
\text { design that meets } \\
\text { multiple } \\
\text { constrains (e.g. } \\
\text { user needs) or } \\
\text { going back to } \\
\text { idea generation }\end{array}$ & $\begin{array}{l}\text { Demonstrating the } \\
\text { promise of an } \\
\text { entrepreneurial } \\
\text { approach in relation to } \\
\text { alternatives }\end{array}$ \\
\hline $\begin{array}{l}\text { Knowledge } \\
\text { building }\end{array}$ & $\begin{array}{l}\text { Documenting, } \\
\text { reflecting on } \\
\text { finding with } \\
\text { disciplinary } \\
\text { knowledge, and } \\
\text { reporting } \\
\text { investigation }\end{array}$ & $\begin{array}{l}\text { Documenting and } \\
\text { reflecting on the } \\
\text { process and } \\
\text { solutions and } \\
\text { reporting product } \\
\text { invention process }\end{array}$ & $\begin{array}{l}\text { Documenting } \\
\text { and reflecting on } \\
\text { design process } \\
\text { and reporting } \\
\text { design invention }\end{array}$ & $\begin{array}{l}\text { Documenting and } \\
\text { reflecting on } \\
\text { entrepreneurial process } \\
\text { and branding and } \\
\text { marketing } \\
\text { entrepreneurial } \\
\text { invention }\end{array}$ \\
\hline
\end{tabular}


Adaptation of such complex issue, as such project is, requires trainig of the teachers involved. A teacher, to be successful, must be trained in each of the basic dimensions knowledge, abilities, and relationships. These dimensions are mutually interwoven in the process of teaching. Every day, at every lesson, they are applied jointly. The teacher is, at the same time, using, e.g. his knowledge of the forces, pressure, relevant pupil's representations; his abilities to aim the attention of the group of pupils, to manipulate equipment and focus pupil's attention to important issues of the experiment used. Also, he enters into interrelationships with pupils and this should not be regarded as something odd. Each Physics teacher is a teacher of learners and a teacher of content. A teacher is fulfilled, happy, if he is well educated and trained, if he has well developed all three dimensions knowledge, abilities, and relationships, if there is an order in his ideas and attitudes. (Demkanin, P. 2018). We also should, at least briefly mention, that sustainable deep education of pupils, as well as teachers, could have impact on their personality. Even if engenerring and enterpreneurship practicies are usually well connected to a organised character, which is the socially favoured profile in secular Western cultures (Demkanin, P., Gergel'ová, B. 2017), (Cloninger, 2013), in our work we try to develope also selftranscendece, which leads to the creative character rather than the organised characters (Demkaninová, D. 2015).

\section{Methodology}

By taking to account what we present above, we suggest implementation of co-inventive student projects. In such projects students work in teams of 4-6 members. Aim of the project is to create a usable product. The product can be a functional device of any kind or even a service. One of the main features of co-inventive projects is, that the product is developed, improved and upgraded by students. During the process of invention students must ask similar questions as scientists and engineers ask. This help students to better understand how science and engineering works and how science data are obtained or how discoveries and inventions are made. Working on a functional product makes acquired knowledge relevant and graspable, because students have an impression that they do something meaningful. Students do what they want to do, because they work on an invention of a product that is their own idea they had come up with. Development of a functional product is iterative process that involves innovation, improvements and upgrades. To improve the product, it is necessary to bring new creative ideas, to analyze limitations and flaws and to receive feedback and opinion from experts and users. Many of this is possible through scaffolding by teacher. During the process of invention, it is often needed to verify, research or discover dependence or relation between physical quantities associated with usage for which is the product intended. Therefore, project needs to be carried out at school in well-equipped laboratory or workshop. During the development of 
a product students must apply already acquired skills, knowledge and practices but also to develop new ones. This kind of learning method helps to create conditions for crosscurricular learning in an inspirational and challenging environment.

In co-invention project students work in small groups so it brings positive but also negative aspects of team work. Therefore we took to account reccomendations of (Demkanin,P., Gergel'ová, B. 2017). Also within this type of project, students with knowledge in some contexts well developed via informal and unformal education can utilise such knowledge and abilities and can take a role of a student-expert. The method student-expert is described in (Chalupková, S. Demkanin, P. 2011).

On the basis briefly mentioned above, we have designed activities supporting development of science and engineering competences that students may need during the process of invention. These activities we have done with students before realization of the project.

We have carried out pilot iteration of co-inventive student project in two classes of 12 years old students. Teams consisted of 5 members. We plan to deeper evaluate the results of pilot realization of the project. Next year we will realize following iteration on larger sample of students.

\section{Realization}

Project was carried out through four weeks which provides 8 physics lessons. Our effort was to set out no restrictions for the product so that creativity of children would not be limited. The assignment was to „,construct or create a usable, functional product “. There were no strict instructions or procedure that they should follow (Velmovská. K., Bartošovič, L. 2016). In our conditions students had very limited rescources. Thay had to obtain most of material and needed tools by themselves.

In the first phase studnets come up with ideas for their product. They have a discussion about which idea they would develop. Than they start to plan and organize the work which includes obtaining material, drawing sketches and blueprints, dividing work among team members.

Next step is to create a prototype of the product. Construction a prototype reaveals many obstacles and complications associated with development of a product. Students find out limits and difficulties in the process of construction. Prototype of the product usually does not funcion well or is unstable, but is very important for next phase.

Students have personal empirical experience gained in everyday life that affect physical intuition. According to diSessa (2014), physical intuition consists of large amount of "pprims" (phenomenological primitives), which are schemata that provide sensibility and 
naturalness of everyday phenomena. Example of a p-prim is a scheme "the closer, the stronger". During the project there are possibilities to form and advance these p-prims or even to link them with physical quantities or physical laws.

To better illustrate positive aspects of co-invention projects we show example. One of the teams in our class decided to construct a catapult. The first issue that the team had to deal with was to choose a source of energy that would be used to toss projectiles. After few nonproductive ideas we have pointed out what they have learned in previous semester about properties of solids. Students remembered flexibility of materials and suggested to use a spring. After drawing some sketches they gathered available resources and material and start to build. Prototype of the catapult was very simple and had many shortcomings (Fig.1).

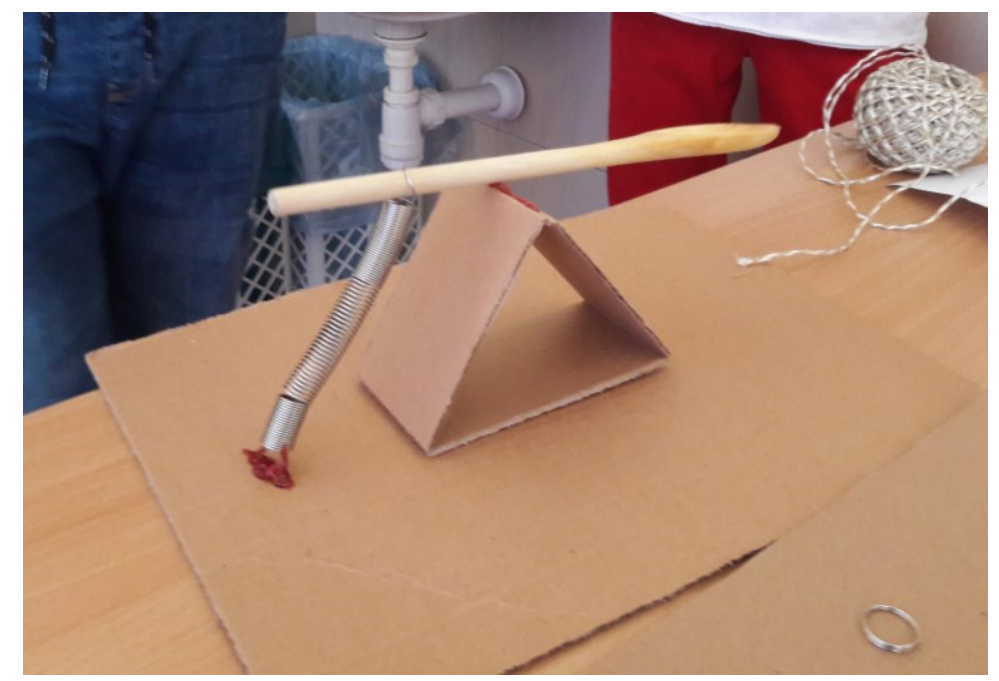

Fig.1. Prototype of a catapult constructed by a group of students at Súkromná základná škola in Bratislava, Slovakia. April 18, 2018.

We provided feedback and review of the product. Within scaffolding we activated a p-prim "the further from axis of rotation, the greater the effect". Students gain this scheme in everyday life for example when opening a door. So they came to conclusion that catapult will toss projectiles further, if they fix the spring at the end of the cooking spoon rather than in the middle between axis of rotation and the end of the spoon. Another problem was, that the spring was not able to stretch enough. So in next iteration they propped the spoon higher above the platform. Upgraded version of catapult was far better, but the product still needed some innovations. While loading the catapult, projectile would fall off because the 
spoon was not deep enough, so they needed to modify the spoon to prevent projectiles from falling off. Because students had limited resources it was challenge for them to fix the spoon to the supporting structure so that it could rotate. Their first idea was to use a metal ring that they fixed to the frame and they inserted the spoon through it. Diameter of the ring was greater than the spoon so it was leisure. With our help they found a better solution. They used two syringes with different diameters. They cut the bigger in half and fixed both parts to the frame so that there was a gap between them. Than they made a hole through smaller syringe and students inserted the spoon through the hole so that it was perpendicular to the syringe. The result was more sutisfiing (Fig.2).

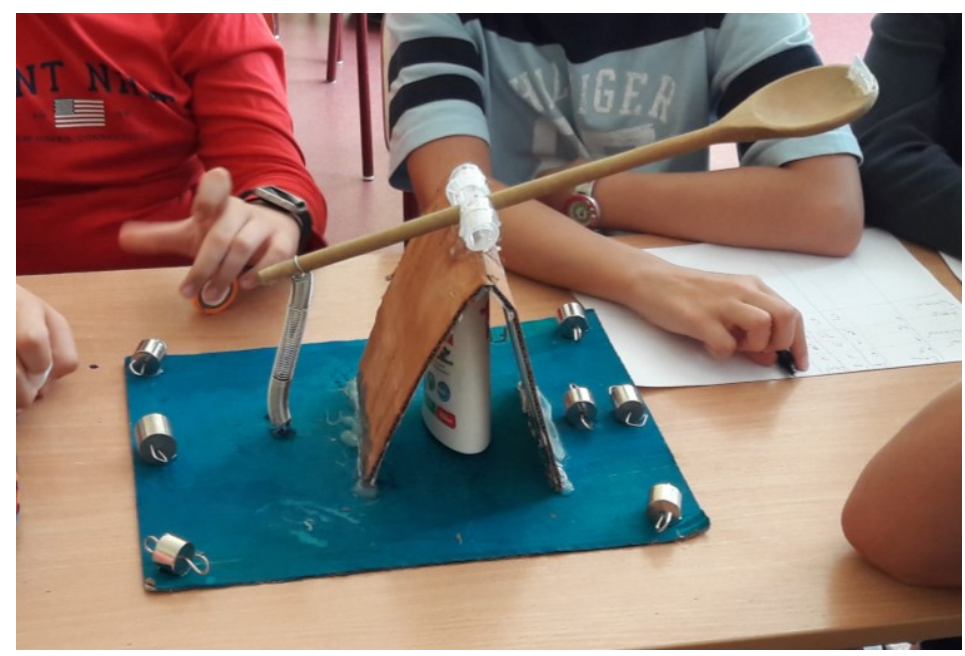

Fig.2. Upgraded version of the catapult created by the group of students at Súkromná základná škola in Bratislava, Slovakia. May 9, 2018.

\section{Analysis}

Pilot realization of co-inventive projects has revealed many aspects that need to be taken to consideration and improvement. In the pilot study we analysed the work qualitatively. Our analysis we have focused on personal engagement (personal significance, interest, curiosity, personal input, initiative, wrok with and for the team); exploration (epistemic focus, idea generation, activity, knowledge seeking from table 1; background information used, relevance, reliability and sufficiency of the information used; awareness of the significant safety, ethical and environmental issues); analysis (information processing, interpretation of the processed information); evaluation (evaluation of interventions, justifying solutions and knowledge building from table 1), communication (clarity of the presentation of the focus, processes, outcomes, use of school science terminology). 


\section{Conclusion}

Curriculum schedules unsuficient time for physics lessons. Despite of limited conditions, rescources and time, we can state that the project was succesful. Students developed sills in each aspects: personal engagement, analysis, evaluation and communication. Working on a functional product is appealing for students and we had recieved encouraging feedback from them. They worked with intrest and had a positive impression about the project. The least developed aspect of produtcs was entrepreneurial aspect. Students lack skills and experience associated with etrepreneurship. In order to develop such skills we need to design activities that would lead to acquiring such experience.

Since teachers job during these projects is not easy, we plan to prepare methodic guides for teachers. In the future we also plan to create more activities to prepare students for coinvention projects. Activities that would form not just science and engineering practices, but also entrepreneural sills and capabilities. Next iteration will be carried out on a larger sample of students and with deeper evaluatin of extent of developed skills and practices.

\section{Acknowledgements}

The author s grateful to support from the Ministry of Education of Slovak Republic, project VEGA no. 1/0396/18

\section{References}

Cloninger, R.C. 2013. What makes people healthy, happy, and fulfilled in the face of currewnt world challenges? Mens Sana Monographs, 11 (1) 16-24, doi: 10.4103/0973-1229.109288

Demkanin, P. 2018. Concept Formation: Phsics Teacher ad his Know-how and Know-why. In: Journal of Baltic Science Education, [online], 2018, Volume 17, No.1, p.4-7. ISSN 1648-3898 Archived at: $<$ http://oaji.net/articles/2017/987-1519059651.pdf $>$

Demkanin, P. 2013. Preparation of physics teachers from various perspectuives. In: Journal of Baltic Science Education, 2013 Volume 12 No.1 p. 4-5. ISSN 1648-3898.

Demkanin, P., Gergel'ová, B. 2017. Development of Aptitude for Team Work via Physics Education. In: Valovičová, L., Ondruška, J. (editor): From the Roots to Contemporary Education Proceedings of the 20th International Conference DIDFYZ. vyd. New York: AIP Publishing, 2017, ISBN: 978-0-7354-1472-3, doi: 10.1063/1.4974380

Demkanin, P., Velanová, M. 2016. Kl'účové tézy obsahu prírodovedného vzdelávania ako kritérium výberu obsahu pre prírodovedné kurikulum. In: Held L. (editor) Východiská prípravy prírodovedného kurikula pre základnú školu 2020 II. vyd. Trnava: Trnavská Univerzita, s. 21-44. ISBN 978-80-8082-994-0 
Demkaninová, D. 2015. Osobnost' v kontexte ADHD [Persionality in the context of ADHD]. In Herényiová, G. ADHD v bio/psycho/sciálnom kontexte. Bratislava. Psychoprof.

Chalupková, S., Demkanin, P. 2011. Student's hobbies as a context for physics teaching. In: Scientia in Educatione, Vol.2, No.1, p. 15-22. ISSN 1804-7106

Krajcik, J., Namsoo, S. 2014. Project-Based Learning in: Sawyer, R.K.(edited by), The Cambridge Handbook of the Learning Sciences, Second Edition, New York: Cambridge University Press, 2014. kap. 14 s. 278-276 ISBN 978-1-107-62657-7

Klentschy, M., \& Thompson, L. 2008. Scaffolding Science Inquiry Through Lesson Design. Vyd. Heinemann, 2008. 144 s. ISBN-13: 978-0325011547

National Research Council. 2012. A Framework for K-12 Science Education: Practices, Crosscutting Concepts, and Core Ideas. Committee on a Conceptual Framework for New K-12 Science Education Standards. Board on Science Education, Division of Behavioral and Social Sciences and Education. Washington, DC: The National Academies Press.

Ruskovaara, E. \& Pihkala, T. 2013. Teachers implementing entrepreneurship education: classroom practices. In: Education +Training, Vol. 55 Issue: 2, s. 204-216.

Sawyer, R.K. 2014 The Cambridge Handbook of the Learning Sciences, Second Edition, New York: Cambridge University Press, 2014. ISBN 978-1-107-62657-7

diSessa, A. 2014. The Construction of Causal Schemes: Learning Mechanisms at the Knowledge Level. Cognitive Science 38(5), 795-850. doi:10.1111/cogs.12131

Velmovská. K., Bartošovič, L. 2016. Developing crtitical thinking skills in physics classes. In: Critical thinking: Theories, methods, and challenges. New York: Nova Science Publishing, 2016. s. 21-43. ISBN 978-1634843492 